\title{
Az időstársadalom várható kihívásait kezelő beavatkozási területek azonosítása
}

Az idősödő társadalom leíró elemzése mellett fontos meghatározni azokat a pontokat, amelyek mentén az esetleges társadalmi torzulások a munkaerő, a közösség és a szellemi vagy fizikai aktivitás tekintetében helyreállíthatók vagy legalábbis javíthatók. A tanulmány szerzői egy 2009-ben elvégzett kérdőíves felmérés eredményei alapján tematikusan végighaladva a lehetőségeken kísérletet tesznek ezeknek a beavatkozási pontoknak az azonosítására és a vizsgált változók közötti összefüggések számszerűsítésére.

Kulcsszavak: idősödő korosztály, IKT, ordinális regresszió, kapcsolatvizsgálat

\section{Szerzői információ:}

Némethné Pál Katalin

közgazdász, GKI Gazdaságkutató Zrt. kutatásvezetô

Pocsarovszky Károly

gazdaságmatematikus, GKI Gazdaságkutató Zrt. kutatásvezetô.

Így hivatkozzon erre a cikkre:

Pocsarovszky Károly, Némethné Pál Katalin. „Az időstársadalom várható kihívásait kezelő beavatkozási területek azonosítása”. Információs Társadalom IX, 4. szám (2009): 81-93. 
Pocsarovszky Károly, Némethné Pál Katalin

\section{Az idôstársadalom várható kihívásait kezeló beavatkozási területek azonosítása}

Egy Predikciós modell megalkotása

\section{Bevezetés}

Európa lakossága drámai módon öregszik - derült ki az Eurostat 2008-as jelentéséból. Napjainkban minden 65 év feletti állampolgárra 4 aktív korú egyén jut, 2060ra azonban ez az arány feleződni fog. A statisztikai elórejelzések arra utalnak, hogy a következő 50 éves periódusban az idôs személyek gazdasági inaktivitása a szociális ellátórendszerek bedóléséhez vezethet. A demográfiai változások hatására jelentôs társadalmi átrendezódés fog lezajlani, amire az országok gazdaságpolitikájának fel kell készülnie. A téma fontosságát jelzi, hogy nemzetközi kutatások és különféle fórumok sora foglalkozik jelenleg is a társadalom idôsödésével, annak hatásaival és a lehetséges kimenetekkel. Kutatómunka folyik többek között az Európai Gazdasági és Szociális Bizottság, valamint az AGE Európai Idôs Emberek Platformja szervezésében is.

A gazdasági aktivitás növelésének egyik eszköze az időskorú, de még munkaképes polgárok foglalkoztatásának ösztönzése. Ahhoz, hogy az idôsek napjaink egyre korszerúbb technikai vívmányai között el tudjanak igazodni és versenyképesek legyenek a tudásalapú társadalom fiatalabb generációival szemben, hatásos felnốttképzési mechanizmus beindítására van szükség. Az idôsek megszerzett képesítésének frissítése, korszerúsítése elengedhetetlen alapkövetelmény a munkaerôpiacon. Az információs társadalomba való integrálódás idôskorban meglehetôsen nehéz feladat, de egyre több képzési program indul, amelyek szakképzett oktatókkal a számítógép és az internet használatát tanítják az idôsebb korosztály számára.

E tanulmány célja olyan összefüggések feltárása, amelyek megvilágítják az 50 év felettiek fizikai, szellemi, illetve közösségi állapota és aktivitása közötti kapcsolatokat, különös tekintettel arra, hogy mindezek hogyan függenek össze a korosztálynak az információs és kommunikációs technológiákhoz (IKT) való viszonyával.

\section{A kutatás alapadatai}

Az elemzés adatbázisát egy kérdőíves felmérés szolgáltatta, amelyet a TÁRKI 2009 májusában a magyarországi 50-75 éves lakosság körében végzett. A felmérés a válaszadók fizikai és szellemi állapotára, aktivitására, közösségi kapcsolataira, valamint kiemelten az IKT eszközökhöz való viszonyára kérdezett rá. A vizsgálat eredményei a magyar lakosság tekintetében nemre, korra, iskolai végzettségre, régióra és településtí- 
pusra nézve reprezentatívak. A minta elemszáma 1003 foó. A kérdôíves kutatás mellett támaszkodtunk a KSH által közzétett lakossági statisztikákra, valamint a GKIeNET Internetkutató és Tanácsadó Kft. nyilvánosan is közzétett felméréseire.

\section{Kapcsolatvizsgálat}

A kutatás céljának megfelelóen a vizsgált korosztály társadalmi helyzetét, a kialakult attitúdök okait és az esetleges beavatkozási lehetốségek helyét, valamint azok várható hatását kellett meghatároznunk. Mindezekhez elsốdlegesen fontos ismernünk magát a sokaságot, amelyet annak állapotjelzó ismérveiból térképezhetünk fel. Az okokra és a beavatkozási lehetôségekre ugyanakkor az aktivitásra vonatkozó kérdések adnak választ.

Az állapotjelzó ismérvek közé soroljuk mindazokat a változókat, amelyek rögzített idôpontban, fényképszerúen jellemzik egy adott személy helyzetét. Tipikusan ilyenek a fizikai és szellemi állapotot meghatározó jellemzók, de ide sorolhatók a társadalmi kapcsolatokat leíró úgynevezett közösségi adatok, továbbá speciálisan ebben a kutatási keretben a vizsgált személyeknek az IKT eszközökhöz való viszonya is.

Az aktivitásra utaló ismérvek egy adott személy tevékenységéról adnak információt. Ezek már nem vagy csak nehezen értelmezhetốk rögzített idôpontban. Ilyenek például a gazdasági aktivitásra vonatkozó jellemzók, amelyek társadalmi szempontból is kiemelt jelentôséggel bírnak. Ugyanakkor az állapotjelzố ismérvekkel párhuzamosan beszélhetünk szellemi, fizikai és közösségi aktivitásról is.

A kutatás során ezeknek a változó-csoportoknak a belsố és külsố vizsgálatát végeztük el. Belsốvizsgálat alatt az elóbbi taxonómia szerint összetartozó változók jellemzését és ezek látens kapcsolatainak feltárását értjük. A jellemzés statisztikai értelemben a leíró elemzést, míg a kapcsolatvizsgálat hipotézisek megerôsítését vagy cáfolását jelenti. A külsố vizsgálat ezzel szemben már nem egy ismérvet tekint alapegységnek, hanem egy egész osztályt, és az egyes osztályok között fellelhetô összefüggések feltárását célozza meg. A kutatás eredményeként olyan modellcsalád leírását végeztük el, melynek segítségével meghatározható a vizsgált társadalmi csoport életkörülményeinek javítását célzó és az egész társadalom számára pozitív hozadékkal járó szakpolitikai intézkedések helye és mértéke.

Itt kell megjegyeznünk, hogy a beavatkozási pontok nem korlátozhatók kizárólag az állapotjelzó vagy az aktivitásra utaló ismérvek vizsgált osztályaira, az intézkedések hatásainak azonban mindenképpen meg kell jelenniük az aktivitás jellemzóiben is, hiszen a beavatkozások csak ekkor hozhatnak hosszabb távon is mérhetô eredményt egyéni és társadalmi szempontból egyaránt.

\section{Módszertan}

A kutatás alapadatait nyújtó felmérés elsôsorban ordinális skálán értelmezhetố változókat eredményezett. Ilyen módon azonban a kapcsolatvizsgálat eszköztára alapvetôen eltér a népszerú statisztikai eszközök alapjául szolgáló arányskála adta lehetóségektốl. Tekintsük példaként a következô relatív gyakoriságokat tartalmazó kereszttáblát: 
1. táblázat

Az iskolai Végæettség és a sæaktudás aktualitása alapján szegmentálható példasokaság kereszttáblája

\begin{tabular}{|l|c|c|c|c|}
\cline { 2 - 5 } \multicolumn{1}{c|}{} & \multicolumn{3}{c|}{ Elégedett a sæaktudásával } & \\
\cline { 2 - 5 } \multicolumn{1}{c|}{} & Igen & Közepesen & Nem & \\
\hline 8 általános & $0,44 \%$ & $1,60 \%$ & $3,94 \%$ & $5,98 \%$ \\
\hline Középiskola & $7,43 \%$ & $11,95 \%$ & $16,62 \%$ & $36,01 \%$ \\
\hline Fóiskola & $16,62 \%$ & $18,08 \%$ & $8,02 \%$ & $42,71 \%$ \\
\hline Egyetem & $8,16 \%$ & $4,37 \%$ & $2,77 \%$ & $15,31 \%$ \\
\hline & $32,65 \%$ & $36,01 \%$ & $31,34 \%$ & $100,00 \%$ \\
\hline
\end{tabular}

A kereszttábla alapján azt kell megválaszolnunk, ha csakugyan lehetséges, hogy átlagosan 1\%-kal növelve a „képzettek” arányát, vajon hány százalékkal változik a szaktudásukkal elégedettek aránya? Mindenekelő́tt definiálnunk kell, mit is jelent pontosan, hogy átlagosan 1\%-kal növekszik a „képzettek” aránya. A képzettség csak adott szinteken értelmezhetô. Ugyanakkor, ha veszünk egy másik sokaságot, amelyben például az egyetemi végzettséggel rendelkezók aránya a jelenlegi $15.31 \%$ helyett 20\%, akkor joggal állítható, hogy ebben az új sokaságban a képzettek aránya növekedett, hiszen ugyanahhoz a képzettségi szinthez arányaiban véve több személy tartozik.

Vegyük szemügyre hasonló módon a fóiskolai végzettséggel rendelkezóket! Amennyiben egy harmadik sokaságban az ebben a kategóriában találhatók száma nagyobb (arányaiban), biztosan megállapíthatjuk, hogy nốtt a foóiskolát végzettek aránya. Az eddigiekkel ellentétben azonban már nem állítható, hogy a „képzettek” száma növekedett, hiszen nem definiáltuk, hogy egy fóiskolai végzettséggel rendelkezô személy vajon „képzettnek” számít-e vagy sem. Még élesebben látszik a probléma, ha a középiskolát végzettek tükrében próbáljuk ugyanezt eldönteni.

Tekintsünk erre a kérdésre a következóképpen: Az egyetemet végzettekról könynyen eldönthetố, hogy ók „képzettek”, hiszen a sokaság legképzettebb 15.31\%-át képviselik. Ugyanakkor ezzel a szemlélettel azt is állíthatjuk, hogy a fóiskolai vagy magasabb képesítést szerzettek képviselik a fenti táblázat szerint a sokaság legképzettebb 58,02\%át. Ugyanígy továbbmenve, a középiskolai vagy magasabb képesítést szerzettek adják a sokaság legképzettebb $94.03 \%$-át. Sejthetô, hogy így már nem okoz problémát annak az értelmezése, hogy a „képzettek” aránya növekedett. Ennek ugyanis éppen azt kell jelentenie, hogy az elóbb megállapított képzettségi szintek (egyetemet végzett, fóiskolai vagy magasabb képesítést szerzett, középiskolai vagy magasabb képesítést szerzett) mindegyikén növekedett az ott elhelyezkedôk aránya. Ekkor, ha összevetjük például a jelen sokaság legképzettebb 58,02\%-át egy olyan sokasággal, amelyben ugyanehhez a képzettségi szinthez a sokaságnak csak 30\%-a tartozik, akkor elmondható, hogy a fenti táblázat által reprezentált sokaságban nagyobb a „képzettek” aránya.

Az igazi kérdést természetesen ennek a számszerúsítése jelenti. Látnunk kell azonban, hogy ez már megoldható. Ehhez az úgynevezett esélyhányados (odds) kiszámítását vesszük alapul. Nevezetesen: az elôzó példában a már említett legképzettebb 58,02\%ról az is elmondható, hogy ebben a sokaságban 58,02\%/(100\%-58,02\%)-kal több képzett van, mint képzetlen, amennyiben a képzettség fogalmát a fóiskolai vagy magasabb 
végzettséget szerzók csoportjára értelmezzük. Két különbözó sokaságra kiszámítva ezt az esélyhányadost ugyanarra a szintre, megállapítható, hogy az adott szintet alapul véve hány százalékkal képzettebb az egyik sokaság a másiknál. Továbbmenve, amennyiben minden képzettségi szinten például 1\%-kal nagyobb esélyhányadost kapunk, akkor azt mondhatjuk, hogy az adott sokaság átlagosan 1\%-kal képzettebb, mint a másik.

Ily módon tehát értelmezni tudtuk az eredeti kérdésünk elsô felét. Vegyük észre azonban, hogy ugyanezt a gondolatmenetet az „elégedettek” tekintetében szintén könnyedén alkalmazni tudjuk, vagyis nem jelent gondot dekódolni például az „adott \%-kal növekedett a szaktudásukkal elégedettek aránya” kijelentést. Mindössze annyit kell megtennünk tehát, most már értve a célt, hogy meg is válaszoljuk az eredeti kérdést. Ezt a már bemutatott táblázaton keresztül illusztráljuk.

Mivel a képzettséggel kívánjuk magyarázni az elégedettséget, alakítsuk át a kereszttáblánkat az alábbi, az előzóvel ekvivalens alakra:

2. táblázat

A sorokhoz tartozó peremgyakoriságokra vetitett kereszttábla

\begin{tabular}{|l|c|c|c|c|}
\cline { 2 - 4 } \multicolumn{1}{c|}{} & Igen & Közepesen & Nem & \multicolumn{1}{c|}{} \\
\hline \multirow{2yyyn}{*}{8 általános } & $7,36 \%$ & $26,76 \%$ & $65,89 \%$ & $5,98 \%$ \\
\hline Középiskola & $20,63 \%$ & $33,19 \%$ & $46,15 \%$ & $36,01 \%$ \\
\hline Fóiskola & $38,91 \%$ & $42,33 \%$ & $18,78 \%$ & $42,71 \%$ \\
\hline Egyetem & $53,30 \%$ & $28,54 \%$ & $18,09 \%$ & $15,31 \%$ \\
\hline & $32,65 \%$ & $36,01 \%$ & $31,34 \%$ & $100,00 \%$ \\
\hline
\end{tabular}

Ekkor az oszlopokhoz tartozó peremgyakoriságokat éppen úgy kapjuk, hogy a sorok peremgyakoriságával mint vektorral jobbról szorozzuk a táblázat belsó értékeit tartalmazó résztáblát mint mátrixot. A kereszttáblának ezt a tulajdonságát szem elốtt tartva határozzuk meg a jelenlegi adatokra vonatkozó elégedettségi és végzettségi esélyhányadosokat.

A képzettségi esélyhányadosokat úgy kapjuk, hogy vesszük a peremgyakoriságok felfelé kumulált arányait, majd minden arányra meghatározzuk a p/(1-p) hányadost. Így az alábbi oszlopvektorokat kapjuk:

\begin{tabular}{|c|} 
Kumulált arányok \\
\hline $100,00 \%$ \\
\hline $94,03 \%$ \\
\hline $58,02 \%$ \\
\hline $15,31 \%$ \\
\hline
\end{tabular}

\begin{tabular}{c|c|}
\multicolumn{1}{c}{ Esélyhányados } \\
\cline { 2 - 2 } & - \\
\cline { 2 - 2 } & 15,74 \\
\hline 1,38 \\
\hline 0,18 \\
\hline
\end{tabular}

A végzettségi esélyhányadost hasonlóan kiszámítva (balról jobbra kumulálással) kapjuk az alábbi vektort:

\begin{tabular}{|l|l|l|}
\hline 0,4848 & 2,1908 & - \\
\hline
\end{tabular}


A leírtak alapján tehát a most kiszámított esélyhányadosok változását kell szemügyre venni. Elsố lépésként tekintsük a független változó 1\%-kal való növekedését, vagyis a képzettek arányának változását. Minden esélyhányados 1\%-kal való megnövelése nem jelent különösebb problémát. Ugyanakkor látnunk kell, hogy a sorvektorként előálló új elégedettségi odds értékek csak a képzettség eloszlásának ismeretében számíthatók ki. A szóban forgó 1\%-kal növelt képzettségi odds értékeket tehát vissza kell transzformálnunk az eredeti eloszlásokra, amit a következó képlet átrendezésével tehetünk meg:

$$
\mathrm{p} /(1-\mathrm{p}) * 1.01=\mathrm{q} /(1-\mathrm{q})
$$

ahol $p$ az eredeti kumulált arány, míg $q$ annak új értéke. Ennek megfelelôen az 1\%-kal növelt képzettségnek megfelelő eloszlás meghatározásához a következô lépéseken kell végigmenni:

\begin{tabular}{|c|}
$\begin{array}{c}\text { Esélyhányados } \\
\mathrm{p} /(1-\mathrm{p}){ }^{*} 1.01\end{array}$ \\
\begin{tabular}{|c|}
\hline- \\
15,74 \\
\hline 1,38 \\
\hline 0,18 \\
\hline
\end{tabular}
\end{tabular}

\begin{tabular}{|c|c|}
\hline \multirow{5}{*}{$\Rightarrow$} & $\begin{array}{l}\text { Kumulált arányok } \\
\text { q }\end{array}$ \\
\hline & $100 \%$ \\
\hline & $94,08 \%$ \\
\hline & $58,26 \%$ \\
\hline & $15,44 \%$ \\
\hline
\end{tabular}

\begin{tabular}{c}
\multicolumn{1}{c}{$\begin{array}{c}\text { Eloszlás } \\
\Delta \mathrm{q}\end{array}$} \\
\cline { 2 - 2 }$\Rightarrow \quad 5,92 \%$ \\
\hline \multirow{4}{*}{$\Rightarrow \quad 35,82 \%$} \\
\hline $42,82 \%$ \\
\hline $15,44 \%$ \\
\hline
\end{tabular}

kapott eloszlás alapján a leírt módon már meghatározható az elégedettségre vonatkozó eloszlás. Szorozzuk az új eloszlásvektor transzponáltjával jobbról az eredeti táblázat belsô értékeit tartalmazó résztáblát mint mátrixot. $\frac{p}{1-p}(1+r)=\frac{q}{1-q} \mathrm{Az}$ így kapott sorvektoron elvégezve az odds-ok kiszámítását, a következố adódik:

$$
0,4862
$$$$
2,1970
$$

Összevetve az eredményeket az eredeti odds értékekkel, látható, hogy az elsố elégedettségi szinten 0,3\%-kal, míg a második szinten 0,28\%-kal emelkedett az esélyhányados értéke. Vajon melyik a tényleges érték? Könnyen belátható, hogy több kategória esetén is különbözó százalékok adódnak az odds-ok növekedésére. Ezeknek az átlagos értékét kell tehát figyelembe vennünk. Súlyozzuk a hozzájuk tartozó peremgyakorisági arányokkal az odds-okat, így az eredmény:

$$
0,3 \% * 0,3272+0,28 \% * 0,3601+0,28 \% * 0,3127=0,2865 \%
$$

Elmondható tehát, hogy átlagosan 1\%-kal növelve a képzettek arányát, 0,28\%-kal nó a: elégedettek aránya a vizsgált sokaságban. Sikerült tehát számszerúsítenünk két ordinális skálán értelmezhetố változó kapcsolatát (annak irányát és mértékét is!). Felmerül azonban kérdés, hogy vajon hogyan változnának az eredmények, ha nem 1\%-os küszöbértéket, hanem például 2\%-osat vennénk, majd a kapott eredményeket visszavetítenénk 
az 1\%-os eltolásra. Belátható (ezt most nem bizonyítjuk), hogy az eredmények a növekedés mértékével konvergensek, vagyis a kapcsolatvizsgálat eredményei a klasszikus regressziós fogalmi kerettel megegyezôen valóban határértékként állíthatók elô.

\section{Belső kapcsolatvizsgálat}

\section{Az idôsödö népesség állapotmutatói}

A jól-lét, illetve az életminôség egyik legmeghatározóbb eleme az egyén fizikai állapota. E fogalom alatt alapvetôen az egészségi állapotot értjük, amely valóban nagy hatással van mind a szellemi állapotra, mind az aktivitásra. Tanulmányunkban az egészségi állapoton túl ideértjük az egészségügyi és jóléti intézményrendszerhez való viszonyt is. A kérdôív a fizikai állapotra vonatkozóan összesen 10 kérdést tartalmazott, amelyek közül az egyén saját egészségi állapotának 1-tól 5-ig terjedô skálán való megítélését tekintettük központi kérdésnek.

Erre a központi ismérvre természetesen hatással van a krónikus betegségek aránya valamely populációban, amelynek $1 \%$-os csökkenése átlagosan $0.43 \%$-os növekedést eredményez az egészségügyi állapot pozitív megítélésében. Hasonlóképpen a rossz látás, a mozgás korlátozottsága vagy a nagyothallás az egészségi állapot rossz megítélését erôsíti. Ugyanakkor az egészségügyi intézményrendszer igénybevételére éppen a központi ismérv gyakorol hatást: ennek 1\%-os romlása igen nagymértékben, 0,61\%-kal növeli az orvos látogatás gyakoriságát és a gyógyszerszedés mértékét. Érdekes ugyanakkor látni, hogy a kiegészítő IKT eszközökkel segített ellátás megítélése alapvetoón független vagy csak elenyészố mértékben függ az egyén egészségi állapotától. A távdiagnózis, az interneten történô recept-felíratás vagy az egészségügyi kérdésekben való internetes informálódás elutasítása mögött rejlô okok tehát inkább magukban az IKT eszközökben, illetve az idősek irántuk tanúsított attitúdjében keresendók, mintsem az egészségügyi rendszer igénybevételében.

A fizikai állapot mellett az egyén szellemi állapota is kiemelten fontos, ha nem fontosabb tényezôje a társadalmi integrációnak. A felmérésben közvetlenül a szellemi állapotra vonatkozóan kevés ismérv szerepelt, azonban ezek is jól tükrözik a tudás szubjektív értékelését az idősödók körében. A kapcsolatvizsgálat középpontját,a tudás aktuális voltára vonatkozó kérdés jelentette, amely az állapotjelzók belsố megítélését reprezentálja, s amelyre nézve a módszerek ismertetésekor is példaként alkalmazott képzettségi szintet lehetett számításba venni, mint magyarázó változót. Ennek alapján elmondható, hogy a szaktudás aktualitásának megítélése erôsen függ a végezettségtól. 1\%-kal megnövelve a képzettek arányát, átlagosan $0.28 \%$-al növekszik a szaktudásukat aktuálisnak tartók aránya.

A szociális kapcsolatok eróssége jellemzố a szellemi állapotra és hatással van nemcsak az aktivitásra, hanem az IKT eszközökhöz való viszonyra is, ezért különösen fontos szerepet töltött be vizsgálatunkban. A felmérésben szereplő kérdéseket három fő csoportra osztottuk. Az elsóben a közvetlen családhoz kötoódó információk kaptak helyet (a család nagysága, családi állapot), amelyek a legszorosabb társadalmi kapcsolat állapotáról adnak tájékoztatást. A másodikba az ennél bóvebb baráti kapcsolatok kerültek, 
míg a harmadik csoportban e kettô megítélése került az elemzés középpontjába (magányosság-érzet, kitốl kaphat segítséget valaki különbözó élethelyzetekben).

Az ismérvek egymás közötti kapcsolatát vizsgálva a magányosság-érzetet emeltük ki központi jelentôségú változóként. Erre ható tényadatok a háztartás nagysága, a családi állapot, a közeli rokonok száma, továbbá - a megkérdezettek szubjektív megítélése alapján meghatározott jellemzóként - a közeli barátok száma, a világ dolgainak megvitatására nyíló lehetôségek, valamint az otthoni segítség elérhetôsége és a bizalom mértéke. A magányosság-érzet ugyanakkor visszahat a segítség elérhetőségének érzékelésére.

A tényadatok közepesen erốs kapcsolatot mutatnak a központi változóval. A rokoni kapcsolatok megléte és az, ha egy háztartásban többen élnek, a magányosság ellen hat. Ugyanakkor a közeli barátok száma (és elérhetôsége) szintén pozitív, bár csak közepesen erôs kapcsolatban (fordított arányban) áll a magányossággal, míg a dolgok megvitatásának és az otthoni segítséghez jutásnak a lehetôsége rendkívül szorosan összefügg a magány-érzettel, és ha ezek adottak, ez átlagosan $0.62 \%$-kal csökkenti a magányosságot. Ugyanakkor az új kapcsolatokkal szembeni általános bizalmatlanság és a magányosság nem összefüggó változók. A központi ismérv nem áll összefüggésben azzal sem, hogy az idôsödók milyen szoros kapcsolati szintról várhatnak segítséget a világ dolgaiban. Azzal ellenben igen, hogy várhatnak-e egyáltalán.

A társas kapcsolatokkal jellemzett közösségi (szociális) állapotról összességében elmondható, hogy az 50-75 év közötti magyarok leggyakrabban házastársukkal élnek együtt egy háztartásban, s átlagosan 5-10 közeli rokonnal és 5 közeli baráttal rendelkeznek, akikre kisebb-nagyobb problémák esetén is számíthatnak. A korosztály 20\%-a érzi magát magányosnak, ami szoros összefüggésben áll a baráti és családi kötelékek számával, független azonban az új kapcsolatokkal szembeni bizalmatlanságtól.

A fizikai, szellemi és közösségi állapot sok tekintetben nincs szoros összefüggésben a vagyoni helyzettel. A tapasztalatok mégis azt mutatják, hogy a megfeleló egészségügyi ellátás, a jobb táplálkozás és a felszabadultabb életvitel nagymértékben javítja az elóbb felsoroltakat, ez utóbbiak azonban a vagyoni helyzet függvényei. Ugyanakkor jelenleg az IKT eszközök igénybevétele szempontjából is kiemelt szerepe van az anyagi lehetóségeknek, mivel az ehhez szükséges eszközök és szolgáltatások pénzbe kerülnek. Ebben a kérdéscsoportban - a korábbiakhoz hasonlóan - objektív és szubjektív jellegú ismérveket vizsgáltunk meg, és elemzés alá vetettünk egy olyan kérdést is, amely a preferenciarendszert reprezentálja.

Az eredmények szerint a vártnak megfelelóen erós pozitív kapcsolat van a jövedelem és a jövedelemmel való elégedettség között. Egy sokaság jövedelmének 1\%-os növelése átlagosan $0.33 \%$-kal fokozza a jövedelemmel való elégedettséget. Összességében elmondható, hogy a megkérdezettek a hazai nyugdíjviszonyoknak megfeleló átlagos jövedelemmel rendelkeznek, s jövedelmük felhasználásában elsốdlegesen a család támogatását preferálják, IKT eszközök vásárlására kevesebb mint 5\%-uk mutat hajlandóságot.

Az informatika terjedésével és az infokommunikációs eszközök széleskörú használatával könyvtárnyi irodalom foglalkozik. A felmérésben a magyarországi IKT penetrációt csak az 50-75 éves korosztályban vizsgáltuk, és az erre vonatkozó adatokat elemeztük több szempontból. Az elemzés alá vetett kérdések az eszközök birtoklását, a kezelésükhöz való hozzáértést és a birtoklásukra irányuló vágyat, illetve a használatukra való 
hajlandóságot mérték. Mindezeket elsôsorban az online iparággal, az e-kereskedelemmel és az e-közigazgatással kapcsolatban vettük szemügyre, de kitértünk populárisabb termékekre is.

A kapcsolatvizsgálat során egy hozzáértési mutatót (tudja-e használni mobiltelefonját, televízióját, számítógépét?) tekintettünk központi változónak, amely szakértôi feltételezés szerint erôsen korrelál a tényleges használattal, így valóban jól reprezentálja a kérdéscsokrot. Az objektív magyarázó változókat az IKT eszközök (számítógép, internet, mobil internet, gps, tv, digitális fényképezôgép, játékkonzol) meglétére vonatkozó kérdések alkották. A szubjektív független változók a szégyen és a bizalmatlanság érzete, valamint a mobiltelefon használatának gyakorisága voltak. A hozzáértésre visszavezethetố változókat a vásárlási hajlandóság és az IKT eszközökre szánt pénzöszszeg tömörítette.

Az eszközök hiánya a vártnak megfelelően csökkentette a hozzáértést is. IKT eszközökkel 1\%-kal kevésbé felszerelt sokaságban átlagosan $0.34 \%$-kal csökken a hozzáértést mutató változó. (Ez alól egyedül a mobil internet-elófizetés bizonyult kivételnek, ennek figyelembe vételét azonban mellőztük, mert a csekély számú válasz miatt ez nem volt statisztikailag elfogadhatóan szoros kapcsolatként értékelhetô.) A tudatlanság miatti esetleges szégyenérzet (illetve ennek hiánya) és az IKT iránti bizalmatlanság hasonlóan elenyészố mértékben (rendre $0.04 \%$-ban és $0.16 \%$-ban) hatott a hozzáértésre. Az új eszközök vásárlási szándéka a feltételezéseinknek megfelelően pozitív kapcsolatot mutatott a kompetenciával (növekvố hozzáértés $0.21 \%$-ban növelte a vásárlási szándékot), és hasonlóan erôs kapcsolat fedezhető fel az új eszközökre szánt összeg és a hozzáértés között is. Nagyobb szakértelem nagyobb ráfordítási hajlandóságot is jelent, és megfordítva. 1\%-kal növelve a hozzáértók arányát, 0,27\%-al nó átlagosan a ráfordítási összeg nagysága.

Bár IKT eszközökkel az idôsödő korosztály az országos átlaghoz hasonlóan van ellátva, a rendszeres használat tekintetében jóval elmarad attól. Az idôsek nem érzik kellemetlenül a hozzáértés hiányát, azonban hasonló mértékú bizalmatlanság érzékelhetố itt is, mint a közösségi kapcsolatok esetében. Ennek megfelelóen a vásárlási hajlandóság is átlagosan csekély mértékú, bár az IKT eszközök kezlésében való jártassággal pozitív kapcsolatban áll.

\section{Az idôsödó népesség aktivitási mutatói}

A gazdasági aktivitás összetett probléma az idôsödő népesség körében. Ennek egyik összetevője az a közismert tény, hogy az átlagos nyugdíjba vonulási kor Magyarországon jóval alacsonyabb, mint az öregségi nyugdíj korhatára. A korkedvezményes, elô- és rokkant-nyugdíjasok nagy száma egyre nagyobb terhet ró az ellátó rendszerre. Ugyanakkor az idôskorral megváltozó teherbíró képesség megnehezíti a korosabb munkavállalók számára a hagyományos foglakoztatási struktúrában való helytállást. Kézenfekvố az a feltételezés, hogy a rohamosan fejlődő információtechnológia ezen a téren megoldást kínál, hiszen ezek az eszközök lehetôséget nyújtanak a kötetlen vagy részmunkaidốs munkavégzésre, a távmunkára és egyéb atipikus foglakoztatási formákra. Az idôs emberek számára ez rugalmasabb, az egészségi és a családi helyzethez alkalmazkodó munkavállalási konstrukciókat tesz lehetôvé. 
Az időskori gazdasági aktivitás vizsgálatakor is összevetettük egymással az objektív és szubjektív ismérveket, A kapcsolatvizsgálat során elsôsorban az aktív korú munkanélküliségre, mint központi ismérvre lehet felfúzni a többi változót. Problémát jelent azonban, hogy a tényismérvek nem értelmezhetók ordinális skálán, ugyanakkor a nominális (asszociációs) kapcsolatvizsgálat sem vezet értelmes eredményre, hiszen a szubjektív magyarázó változóként kijelölendô munkavállalási hajlandóságra vonatkozó kérdések kizárólag a nem-dolgozók körére értelmezhetók. Mindezek miatt a munkavállalási hajlandóságra vonatkozó „napi hány órában vállalna munkát” kiegészítettük egy utolsó kategóriával, azokkal akik foglalkoztatottak valamilyen formában, hiszen esetükben bizonyosan van hajlandóság.

Összességében megállítottuk, hogy az 50-75 éves korosztály nem dolgozó tagjai körében a hivatalosan mértnél jóval nagyobb mértékú, több mint 20\%-os a munkavállalási hajlandóság. Annak ellenére, hogy a nem dolgozók több mint 90\%-a nyugdíjas, mindössze 43\%-uk jelölte meg a nyugdíjazást a munkától való távolmaradás tényleges okaként. A munkavállalásért sok kényelmetlenséget is vállalnának az álláskeresôk, azonban az otthonról végzett távmunkát, valamint a „fizetôs” továbbképzéseken, tanfolyamokon való részvételt többségükben elutasítják. (Az ingyenes tanfolyamokra ez nem vonatkozik.)

A gazdasági aktivitás mellett vizsgáltuk a közösségi aktivitást is, ami szoros kapcsolatban áll a közösségi állapottal kapcsolatban leírtakkal. Míg azonban ott elsósorban a kapcsolatháló erốsségére, illetve annak az adott szituációktól függó értékére vonatkoztak a vizsgálataink, addig itt a hosszabb távú, illetve rendszeresen végzett közösségi tevékenységek kerültek elốtérbe. A kérdések osztályozása ugyanakkor hasonló volt: a közvetlen és a tágabb környezetet elemeztük.

Adott kapcsolati háló erôsség mellett a tényleges aktivitás szintje a vártnál sokkal alacsonyabb. Míg szükség esetén az idôsödók családi körból szinte mindig számíthatnak segítségre, addig a rendszeres kapcsolattartás a rokonokkal már sokkal alacsonyabb szintú. Rokonaikkal, barátaikkal általában heti, illetve havi rendszerességgel lépnek kapcsolatba. Az elóbbiekkel inkább személyesen és a népszerúbb IKT eszközök (elsốsorban mobiltelefon, sms) útján, míg az utóbbiakkal az online alkalmazások (skype, e-mail) segítségével érintkeznek.

A belsố kapcsolatvizsgálat központi ismérve az a közösségi aktivitást jelzố összetett mutató volt, amely a találkozások gyakoriságát értékeli. A szakmai segítségnyújtás gyakorisága, valamint a közvetlen környezettel az IKT eszközökön keresztül megvalósuló kapcsolatfelvétel gyakorisága erôs pozitív hatással van a közösségi aktivitást jelzó mutatóra (rendre $0.29 \%$-ban és $0.51 \%$-ban), bár a szigorú értelemben vett családi aktivitás elmarad a várt erốsségi szinttól. Ugyanakkor az interneten való kapcsolatfelvételre szintén komoly hatással van az úgynevezett offline közösségi aktivitás. Ilyen vetületben tehát az online szociális háló erôsítésére az offline kapcsolatoknak is hatása van.

Általánosságban kijelenthetjük, hogy bár gyengébb közösségi aktivitást tapasztalhatunk, mint amilyen a közösségi állapot esetében feltérképezhetô volt, ugyanakkor az online világban, IKT eszközök útján fenntartott kapcsolatok éppen az offline környezetben mutatkozó lazább kötődést erósítik pozitív módon.

A szellemi aktivitás szintén szoros összefüggésben áll a korábban vizsgált szellemi állapottal. Itt három kulcskérdést vizsgáltunk meg arra vonatkozóan, hogy szakmai- 
lag, illetve a magánéletben milyen rendszerességgel képezik magukat a válaszadók, és mennyi idốt fordítanak tudásuk szinten tartására.

A szellemi aktivitásra vonatkozó kérdések nem hoztak újdonságot a szellemi állapot, illetve a tanfolyamokon való részvételi hajlandóság ismeretében. Az ezekre kapott válaszok alapján azonban úgy túnik, hogy a rendszeres információgyuujjtés fontos eleme az idôsek mindennapi életének.

Mivel társadalmi szinten elsôsorban a szakmai képzés fontosságát kell kiemelnünk, a kapcsolatvizsgálat során ez jelentette a központi kérdést, amelyre két másik, a szellemi fejlődést méró ismérv volt hatással (részt vett-e tanfolyamon, milyen gyakran végez intellektuális tevékenységet).

Az eredmények szerint az intenzív otthoni agytorna (például keresztrejtvényfejtés) gyakoriságából nem vagy csak nagyon kis mértékben következik, hogy az adott személy a munkájához vagy szakmájához kapcsolódó tanfolyamon is részt vesz. Ezzel szemben a magánjellegú továbbképzés (például fớzốtanfolyam, nyelvtanfolyam, tánciskola) közepesen erốs pozitív összefüggésben áll a munkához kapcsolódó ismeretszerzéssel. A magánjellegú tanfolyamokon résztvevók arányát $1 \%$-kal növelve $0.22 \%$-kal nó a szakmai továbbképzésen résztvevoók aránya.

Az egészségi állapot megórzésének egyik szükséges feltétele a fizikai aktivitás, ami pozitívan hat az egészségre. Ez a kapcsolat azonban fordított irányban is fennáll, mivel a fizikai állapot (az egészség) is kihat az aktivitás mértékére. Erre nézve két kérdéscsoportot vizsgáltunk meg, amelyek közül az elsố kizárólag az egyénhez kapcsolódó aktivitási formákat fedi le (szokott-e rendszeresen ház körüli munkát végezni, sportolni), míg a másodiknak társadalmi vonzata is lehet (szokott-e színházba, könyvtárba járni, végez-e önkéntes munkát, közösségi tevékenységet).

Összességében a két változócsoport jól írja le a fizikai aktivitást, amelyek alapján a megkérdezettek átlagosan legalább havonta egyszer intenzív testmozgást végeznek. Az is megállapítható, hogy amennyiben a sokaságban 1\%-kal nó az intenzív testmozgást végzók aránya egyéni szinten, átlagosan 0,08\%-kal nố a fizikailag aktívak aránya.

\section{Külső kapcsolatvizsgálat}

Az állapotjelzố és az aktivitásra utaló változók belső kapcsolatainak megismerését kiegészítendő, megcéloztuk a közöttük meglevő látens összefüggések feltárását is. Ehhez kiszámítottuk ki az alábbi kapcsolattábla adatait, amelyek a korábban kiemelt központi ismérvek közötti közvetlen kapcsolatokat reprezentálják.

A táblázat alapján látható, hogy a fizikai állapot elsôsorban a szellemi állapotot és a gazdasági aktivitást befolyásolja. A szellemi állapot szintén a gazdasági aktivitásban, valamint a szellemi aktivitásban játszik fontos szerepet,. A közösségi állapot a fizikai aktivitásra és a fizikai állapotra gyakorol hatást érdemben. A vagyoni állapot a gazdasági aktivitás tekintetében meglepetést hozott, hiszen e kettô függetlenként értékelhetố, Megállapítható, hogy a munkavállalási hajlandóság alapvetốen független az aktuális vagyoni állapottól. Megjegyzendô azonban, hogy a vizsgált sokaságban igen kevés kiemelkedố vagyoni helyzetben levố személy volt, így az eredmények ennek is tulajdoníthatók. 
Az IKT eszközök használata és a hozzáértés ezek kezeléséhez a szellemi állapottal és a szellemi aktivitással, valamint a gazdasági aktivitással hozható szoros összefüggésbe. A gazdasági aktivitás és a munkavállalási hajlandóság hasonlóképpen a szellemi állapotra vezethetố vissza. A közösségi aktivitás a fizikai aktivitást erósíti, és a fizikai állapotra is hatással van. A szellemi aktivitás legerôsebben a szellemi állapotban és a gazdasági aktivitásban jelenik meg, a fizikai aktivitás pedig a közösségi aktivitásban játszik kiemelkedő szerepet és természetes módon hatással van a fizikai állapotra, a táblázatban mutatott értékeknek megfelelő mértékben.

3. táblázat

A változók közvetlen kapcsolatai

\begin{tabular}{|c|c|c|c|c|c|c|c|c|c|c|}
\hline & & 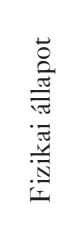 & 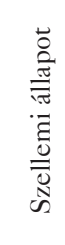 & 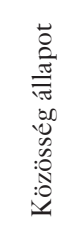 & 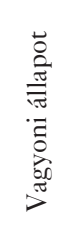 & 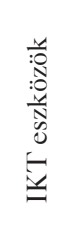 & 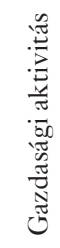 & 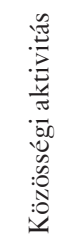 & 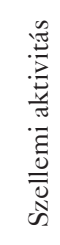 & 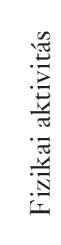 \\
\hline \multirow{5}{*}{ 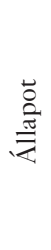 } & Fizikai & 1.00 & 0.36 & 0.31 & 0.28 & 0.29 & 0.37 & 0.38 & 0.26 & 0.20 \\
\hline & Szellemi & 0.36 & 1.00 & 0.22 & 0.25 & 0.37 & 0.48 & 0.32 & 0.39 & 0.00 \\
\hline & Közösség & 0.28 & 0.20 & 1.00 & 0.28 & 0.21 & 0.10 & 0.22 & 0.16 & 0.37 \\
\hline & Vagyon & 0.27 & 0.29 & 0.34 & 1.00 & 0.19 & 0.00 & 0.30 & 0.25 & 0.42 \\
\hline & IKT eszközök & 0.33 & 0.38 & 0.20 & 0.16 & 1.00 & 0.42 & 0.34 & 0.41 & 0.21 \\
\hline \multirow{4}{*}{ 莺 } & Gazdasági & 0.38 & 0.44 & 0.10 & 0.02 & 0.37 & 1.00 & 0.20 & 0.26 & 0.07 \\
\hline & Közösség & 0.31 & 0.28 & 0.19 & 0.19 & 0.30 & 0.20 & 1.00 & 0.28 & 0.49 \\
\hline & Szellemi & 0.26 & 0.38 & 0.15 & 0.22 & 0.37 & 0.30 & 0.27 & 1.00 & 0.14 \\
\hline & Fizikai & 0.37 & 0.27 & 0.20 & 0.30 & 0.28 & 0.19 & 0.41 & 0.32 & 1.00 \\
\hline
\end{tabular}

Megjegyæés: A sorok a magyarázó, míg az oszlopok a függó változók.

A kapott táblázat mint mátrix hatványozásának segítségével a közvetlen kapcsolatokon túl a közvetett értékek is számszerúsíthetók. A fizikai állapot például hatással van a közösségi aktivitásra, ami viszont kihat a fizikai aktivitásra. Ugyanakkor a fizikai állapot közvetlenül is megjelenik a fizikai aktivitást jelzô változóban. E kettô összege adja tehát a tényleges kapcsolatot, amely egyszerúen is kiszámítható a mátrix második hatványával. Az eredményt az alábbi táblázat mutatja:

A közvetett kapcsolatokat is figyelembe véve már sokkal árnyaltabb kép adódik. Ugyanakkor hangsúlyoznunk kell, hogy az említett változók kizárólag a saját skálájukon értelmezhetók, és a beavatkozási lehetôségek pontos gazdasági vonzatai csak ezeknek az értelmezési skáláknak a „forintosítása” esetén adhatók meg az eredmények alapján.

A fizikai (egészségi) állapot alapvetôen a szellemi állapot és a fizikai aktivitás függvénye, továbbá - érdekes módon - erôsen összefügg az IKT kompetenciával. Hasonlóképpen, a szellemi állapotra leginkább az IKT kompetencia erósítése van hatással. 1\%- 
kal növelve az IKT hozzáértók arányát, 1,46\%-kal nó a tudásukkal elégedettek aránya. A közösségi állapotot leginkább a fizikai állapot befolyásolja. Ugyanakkor a vagyoni állapot esetében csak gyengébb kapcsolatok figyelhetók meg. Az IKT eszközök elfogadásának erôsítéséhez elsốsorban a szellemi állapoton és a szellemi aktivitáson kell javítani. A munkavállalási hajlandóság is ettól, illetve az IKT eszközök használatától függ. A közösségi aktivitás a fizikai állapothoz és aktivitáshoz köthetố legszorosabban. A szellemi aktivitás szintén az IKT-kompetenciától függ, míg a fizikai aktivitás mértékét elsốsorban a rendelkezésre álló vagyon határozza meg.

4. táblázat

A közvetett kapcsolatok számszerüsitése

\begin{tabular}{|c|c|c|c|c|c|c|c|c|c|c|}
\hline & & 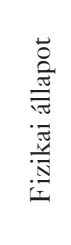 & 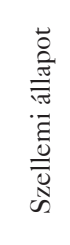 & 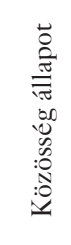 & 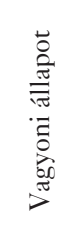 & 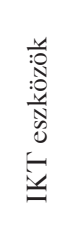 & 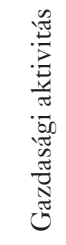 & 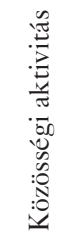 & 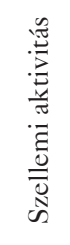 & 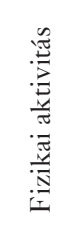 \\
\hline \multirow{5}{*}{$\begin{array}{l}\stackrel{\sqcup}{0} \\
\stackrel{\Xi}{\Xi} \\
\stackrel{\bar{Z}}{Z}\end{array}$} & Fizikai & 1.79 & 1.40 & 1.04 & 0.98 & 1.23 & 1.26 & 1.35 & 1.17 & 0.94 \\
\hline & Szellemi & 1.35 & 1.84 & 0.88 & 0.88 & 1.36 & 1.45 & 1.23 & 1.34 & 0.58 \\
\hline & Közösség & 1.06 & 0.93 & 1.42 & 0.91 & 0.89 & 0.65 & 0.98 & 0.83 & 1.09 \\
\hline & Vagyon & 1.12 & 1.11 & 1.04 & 1.51 & 0.94 & 0.57 & 1.17 & 1.03 & 1.24 \\
\hline & IKT eszközök & 1.35 & 1.46 & 0.85 & 0.79 & 1.78 & 1.40 & 1.30 & 1.40 & 0.88 \\
\hline \multirow{4}{*}{ 营 } & Gazdasági & 1.23 & 1.36 & 0.59 & 0.46 & 1.21 & 1.65 & 0.94 & 1.04 & 0.47 \\
\hline & Közösség & 1.25 & 1.21 & 0.82 & 0.85 & 1.18 & 0.97 & 1.72 & 1.16 & 1.31 \\
\hline & Szellemi & 1.13 & 1.33 & 0.72 & 0.81 & 1.26 & 1.13 & 1.10 & 1.64 & 0.71 \\
\hline & Fizikai & 1.35 & 1.23 & 0.88 & 1.02 & 1.18 & 0.96 & 1.40 & 1.23 & 1.59 \\
\hline
\end{tabular}

Megjegyzés: Az oszlopokban azonosítható változókra leginkább ható sorokat kiemeltük.

\section{Összefoglalás}

A kutatás során az 50-75 éves magyar lakosságot vizsgáltuk a munkaeró piaci helyzete, közösségi kapcsolatai, fizikai és szellemi állapota, illetve aktivitása és az IKT eszközökhöz való viszonyulása szempontjából. Elôször az elemzési szempontrendszert adó taxonómia alapján belsố leíró elemzés és kapcsolatvizsgálatok útján feltártuk a vizsgált változók összefüggéseit az egyes témakörökön belül. Második lépésként az egyes változócsoportok közötti viszonyt számszerúsítettük az ordinális regresszió módszerének célszerú módosítása alapján.

Az eredményeket a következókben foglalhatjuk össze:

Sikerült számszerúsítenünk két ordinális skálán értelmezhetô változó kapcsolatát, meghatározva annak irányát és mértékét is. 
Feltártuk, hogy a vizsgált korosztály alapvetôen elutasító az IKT eszközökkel szemben, s ez elsốsorban olyan ismeretek és készségek hiányából adódik, amelyek képzés segítségével pótolhatók. Ugyanakkor a képzési lehetôségekkel az idôsek csak akkor hajlamosak élni, ha ez nem követel tólük anyagi áldozatokat.

A közösségi állapot és aktivitás kiemelt szerepet tölt be a vizsgált sokaság más ismérvekkel jellemezhetô életminóségében. Az 50-75 közötti magyar lakosság alapvetốen házastársi kapcsolatban él egy háztartásban, átlagosan 5-10 közeli rokonnal és átlagosan 5 közeli baráttal rendelkezik, akikre kisebb-nagyobb problémák esetén is számíthat. A korosztály 20\% érzi magát magányosnak, ami szoros összefüggésben áll a baráti és családi kötelékek számával, független azonban az új kapcsolatokkal szemben megnyilvánuló bizalmatlanságtól.

A korosztály vagyoni állapota közepesnek értékelhetố, és azt elsôsorban a nyugdíjak határozzák meg. Az anyagi helyzet szubjektív megítélésére a fizikai állapot és a közösségi aktivitás is erôs hatással van.

A foglalkoztatás lehetôségeire nézve kimutattuk, hogy a korosztály tagjainak a munkavállalási hajlandósága a statisztikailag ismertnél jóval nagyobb mértékú, több mint 20\%-os. Sokan szívesen dolgoznának részmunkaidóben nyugdíjasként is. Erre való hajlandóságuk a szellemi állapot és az IKT-kompetencia függvénye.

Az IKT eszközök használatában való jártasság elôsegíti a társas kapcsolatok és a közösségi aktivitás erôsítését, valamint a szellemi állapot fejlődését is.

\section{Irodalom}

P. McCullagh (1980): Regression models for ordinal data. Journal of the Royal Statistical Society, Vol. 42, No. 2, pp. 109

Hunyadi László és Vita László (2003): Statisætika közgaะdásæoknak. Budapest, KSH

J. F. Hair (2006): Multivariate Data analysis. Prentice Hall

Németh Balázs (2007): A lifelong learning paradigma értelmezése. (Doktori disszertáció, Pécsi Tudományegyetem) 